\title{
THE LEFT-RIGHT DIMENSION IN LATIN AMERICA
}

\section{JOSEP M. COLOMER}

\begin{abstract}
$\underline{\text { ABSTRACT }}$
We present voters' self-placement and 68 political party locations on the left-right dimension in 17 Latin American countries. Innovative calculations are based on data from Latinoba rometer annual surveys from 1995 to 2002 . Our preliminary analysis of the results suggests that most Latin American voters are relatively highly ideological and rather consistently located on the left-right dimension, but they have very high levels of political alienation regarding the party system. Both voters' self-placement and the corresponding party locations are presently highly polarized between the center and the right, with a significant weakness of leftist or broadly appealing 'populist' positions.
\end{abstract}

Keywords: Political ideology, Left-right dimension, Political parties, Electoral competition, Latin America. 


\section{INTRODUCTION}

The left-right ideological dimension is very important in democratic politics. As is well known, it originated as a symbolic representation of political representatives' relative stands in late 18th century France, but it has spread as widely as to be called the 'political Esperanto' of our times (Laponce 1981). In modern politics and mass media-dominated political communication, it is usually assumed that, by using a simplified, encompassing ideological dimension, party leaders and candidates can transmit useful information on policy programs which can be understood by voters without paying high costs. It has, thus, been postulated that a party position on the leftright dimension can synthezise a number of party policy positions on many issues (Downs 1957) -an intuition that has repeatedly been submitted to scrutiny and empirically tested (see, for instance, Robertson 1976, Budge et al 1987, Budge et al 2001).

The left-right dimension has been found to be the most common one across developed democratic countries. In the short term, parties, of course, come together and move apart in response to imperatives of party competition, while they also try to give saliency to different policy issues and alternative dimensions on which they can expect to be located in advantageous positions (Stokes 1963, Riker 1993). But, in the long term, parties tend to stay on stable positions relatively to each other and not 'leapfrogging'. The organizing role of the left-right aggregative or synthetic dimension facilitates basic exchanges between voters and party leaders. In fact, most people in most developed democratic countries are able to place themselves and locate political parties on the left-right dimension. Consistent party positions on this dimension have been identified by different means, including mass voters' polls (Sani and Sartori 1983, Inglehart and Klingemann 1987), expert judgments (Castles and Mair 1984, Laver and Hunt 1992, Huber and Inglehart 1995), and contents analysis of party manifestos (Budge and 
Klingemann 2001, Laver, Benoit and Garry 2003) (see also other sources and discussion in Laver and Schofield 1990, Appendix B). Rela tive party positions on the left-right dimension have been fruitfully used for analyzing such important questions as political representation (Huber and Powell 1994, Powell 2000), party platform and electoral strategies (Budge 1993), governmental coalition formation (Laver and Schofield 1990, Laver and Budge 1992), and party government expenditure (Budge and Keman 1990).

However, the relevance of the left-right dimension has traditionally been dismissed by students of politics in Latin American countries, where it has been supposed that political parties are not strongly ideological oriented, but rather populist, personalistic and clientelistic. Just to mention a few relevant instances, an encompassing encyclopedia of political parties in the region remarked "the general pragmatism and lack of ideological commitment on the part of most political parties in Latin America today" (Ameringer 1992: 5), while a broad comparative study of the same topic stated that political parties "make policy choices that tend to be short-term and erratic; they are more prone to demagoguery and populism" (Mainwaring and Scully 1995: 25).

In the present note we develop a new method based on mass survey data to estimate the proportions of voters able to place themselves and locate their preferred parties on the left-right ideological dimension. Specifically, we present voters' self-placement and 68 political party locations on the left-right dimension in 17 Latin American countries. In a merely exploratory manner, we also suggest that these data can help to discuss such important issues in Latin American politics as the proportions of voters strange to any ideological or political party allegiance, likely to be related to the spread of political 'alienation' and of non-ideological or 'clientelar' relations between parties and voters.

Data are elaborated from responses to Latinobarometer annual surveys from 1995 to 2002. ${ }^{1}$ We think that this kind of data can give strong grounds for applied analyses of mass and 
party politics in the region, without the subjective biases unavoidably introduced by alternative measures such as experts judgments of politicians' estimates. The results summarized in the Tables are the most comprehensive and updated dataset on these notions to date. In Appendix, we also compare our findings regarding party locations with those previously presented with alternative methods for previous periods, fewer countries or different party sets.

In particular, we have innovatively analyzed and crossed individual responses to two questions in Latinobarometer surveys: a) 'On a scale where 0 is left and 10 is right, where would you place yourself?', and b) 'If this Sunday there were elections, which party would you vote for?'. We present in a number of Tables and briefly discuss the following results:

1) Percentage of voters able to place themselves on the left-right dimension from 1995 to 2002.

2) Proportions of voters able to place themselves on the left-right dimension (in question a) but not declaring any party for which they would vote (in question b), and proportions of voters not able of placing themselves on the left-right dimension (in question a), but declaring a party for which they would vote (in question $b)$.

3) Voters' self-placement on the left-right dimens ion, from 0 to 10.

4) Party positions on the left-right dimension, as measured by the average selfplacement of voters (in question a) declaring their preference for the party (in question $b)$.

The analysis of these results suggests that most Latin American electorates and party systems are relatively highly ideological and rather consistently located on the left-right dimension, but they have very high levels of political alienation regarding the party system. Both voters' selfplacement and the corresponding party locations are presently highly polarized between the 
center and the right, with a significant weakness of leftist or broadly appealing 'populist' positions. We conclude with a number of suggestions for further research.

\section{CITIZENS' SELF-PLACEMENT}

The percentages of citizens able to place themselves on the left-right dimension by giving response to question a) above quoted in each of the 17 Latin American countries in Latinobarometer surveys from 1995 to 2002 are presented in Table 1 . The total six- or sevenyear 17-country average is relatively high, 78 percent. $^{2}$ The variance, however, is also relatively high, with the largest proportions of citizens able to place themselves on the left-right dimension found in Uruguay (with a seven-year average of more than 92 percent) and, to a lesser extent, in Brazil (85 percent), and the lowest proportions in Guatemala, Costa Rica, Colombia, Bolivia and Argentina (between 71 and 76 percent).

No temporal trend towards either increasing or decreasing levels of ideological consistency can be identified in the sample, since while the highest values are found for 1997, the average values for the starting and the most recent years, 1995 and 2002 respectively, are about the same, around 72 percent. However, for most counties the seven-year series available reflects only part of their present democratic periods in which the left-right dimension can become relevant, in comparison with no-party, non-ideological official politics in previous authoritarian periods. For more remote periods in the past, the hypothesis that the proportions of voters able to place themselves on the left-right dimension were lower than in recent democratic periods remains open. ${ }^{3}$ 
On the basis of the responses in the most recent survey to the two questions reproduced above, we present proportions of four different types of voters in Table 2. Among those voters able to place themselves on the left-right dimension, we distinguish two groups, respectively declaring or not a party preference (to vote for 'if this Sunday there were elections', according to question b). As a country-average, the two groups have about the same size, about 36 percent of total voters each. In other words, Latin-American ideological voters able to place themselves on the left-right dimension are divided in two halves: those declaring a party preference -- who could be called 'citizens'-- and those not declaring any party preference -who could be considered to be 'alienated' from the party system. The variance, however, is high. The highest proportions of citizens with both ideological self-placement and party preference are found in Uruguay, followed at some distance by Costa Rica, which in both cases are about double than the respective proportions of voters not declaring a party preference. Indeed these two countries are usually considered among the best in democratic quality in the region. On the other extreme, the highest proportions of ideological voters not declaring a party preference are found in Argentina (doubtless reflecting the popular mood expressed by the slogan 'go all them out' at the time the survey was carried out), followed by Ecuador, Guatemala, Panama, Paraguay and Peru. In all these cases the proportions of voters not declaring a party preference are higher than those with such revealed preference.

Among the voters not able to place themselves on the left-right dimension, we also can identify a number of them declaring a party for which they would vote. This non-ideological party allegiance could be related to the spread of 'clientelism', if we consider the latter as a form of non-ideological exchange between politicians and voters. The average value in the region, 5 
percent, is rather low, although it can be under-valuated in a few countries due to survey technical characteristics. ${ }^{4}$ The variance, in any case, is high. In broad accordance with usual estimates, the highest proportions of non-ideological party allegiance are found in Colombia, Ecuador and El Salvador, while the lowest correspond to Uruguay. Although not reflected in the Table, it is interesting to note that values are very similar for all major parties in each country. It seems that the diffusion of non-ideological or presumably 'clientelar' party exchanges is a contagious game: if one party develops such a kind of relations to a significant extent, competing parties in the same country are induced to do it as well.

\section{Table 2 about here}

\section{PARTY'S VOTER LOCATIONS}

Voters' self-placement on the 0 -10 left-right scale is presented for 17 countries in Table 3. It is highly striking that most voters in the survey place themselves either on position 5 (the center) or on position 10 (the right). This suggests, first, high levels of polarization and, second, a strong bias against genuine leftist ideological positions among the electorate. The most leftist average citizens are found in Mexico, with a value of 4.9, actually corresponding almost perfectly to the exact center, while the most rightist are in Honduras and Costa Rica, with values 7.6 and 7.4 respectively. ${ }^{5}$ 
Political party positions on the left-right dimension have been measured by the average self-placement of voters declaring their preference for the party and are presented in Table 4. While similar Tables can be found for most European and developed democratic countries, whether on the basis of expert judgments or by analysis of party manifestos, this is the first largely comprehensive Table presented for Latin American countries on the basis of mass surveys. Parties have been selected for having more than 10 respondents in the survey, so eliminating those with extremely minority support and unreliable results, with a total of 68 parties located. The findings are highly consistent with the assumed dimensionality: the standard deviation is around 2.5 on a scale of 10 points for an average of four parties per country; the confidence interval is in average 1.4 per party. Large confidence intervals may correspond to significant weaknesses of the left-right dimension and the existence of alternative salient dimensions. The largest values correspond to an indigenist party in Bolivia, Eje Pachakutic, which can reflect the saliency of the ethnic dimension in this case, and to most parties in Peru, likely corresponding to the saliency of the authoritarian-democracy dimension in the country at the troubling moment in which the 2002 survey was carried out. For the rest, most parties have confidence intervals that do not overlap with those of their 'neighbors', that is, the parties on contiguous positions along the dimension, thus presenting a consistent ideological continuum from left to right.

Quantitative results are difficult to be compared across countries, since they may reflect different voters' evaluations and ideological contents of the $0-10$ scale. In separate country results some parties are given far left scores, including IU in Argentina, MAS in Bolivia, PC in Chile and FMLN in El Salvador, all with values below 3 (none of them having been in government in present democratic periods). On the far right high values are given to ARENA in 
El Salvador, the two major parties PL and PN in Honduras, and COPEI in Venezuela, all with values above 8 (all of them having been in government in recent times).

A few interesting cases show close convergence of major parties within a country, including especially PAN and FRG in Guatemala, PL and PN in Honduras, and several parties in Panama. There are also a few cases of apparent 'leapfrogging'. The UCR in Argentina has moved in the eyes of the people surveyed in the sample from a traditionally presumed center-left position to the right of the political spectrum, but its average position implies a large confidence interval suggesting that this move has been recent and the party may still attract both traditional center-left and new rightist voters (as reflected in the candidacy for the 2003 presidential election closest to the survey). The jump of the average position of the Colombian Liberal party to the right of the Conservative party may also reflect the extreme factionalization of the Liberals, including their split between government and opposition sides. In Uruguay the convergence between the Colorado and the National parties had already been noted by local experts and observers, having perhaps culminated in recent times, as reflected in the survey, as a result of a long period of Colorado's governments.

As a whole, the party system configurations that can be observed in the Table do not seem to give support to the hypothesis that 'populism' is widespread, at least if 'populism' is defined as party's capability to attract a broad spectrum of voters located on distant positions along the left-right dimension. Certain parties traditionally considered to be 'populist', such as PJ in Argentina and PRI in Mexico, as well as MNR in Bolivia or the Roldosistas in Ecuador, are now gathering the support of segments of voters relatively narrow regarding their ideological self-placement.

Table 4 about here 


\section{CONCLUDING COMMENTS}

The comments included in the above paragraphs are only a first approximation to more thorough analyses of the data and results collected. A preliminary examination suggests that Latin American electorates are relatively highly ideological and rather consistently located on the leftright dimension, although longer-period series and analysis should confirm or reject this view. There are, however, very high proportions of ideological voters not declaring any party vote. In contrast, the proportions of non-ideological voters declaring a party preference seem to be relatively low. In general, the ideological electorate and the party competition in the region appear to be, by early 21 st century, highly polarised between the center and the right, with a significant weakness of positions both on the left side of the spectrum and of 'populism' able to attract voters from a broad variety of ideological positions. The surveys show, however, high variance between countries. Extreme cases include, on one side, Uruguay and Costa Rica, with relatively high levels of voters' ideological consistency and party preference. On the other side, the lowest levels of voters' ideological consistency and party preference are found in Argentina, Colombia and Guatemala.

Beyond these provisional comments, the data and results presented in this note can trigger and support a number of directions in further research. Among them we can suggest the following:

- Relation between the distribution of voters' preferences on the left-right axis and certain characteristics of recent processes of democratization, including pace of change, spread of consensual or adversarial politics, and further political and institutional stability. 
- Relation of voters' capability to place themselves on the left-right dimension and their allegiance or alienation from the party system with stability, performance and durability of democratic regimes.

- Analysis of political representation and consistency between voters' self-placement and governments' party positions.

- Measures of the degrees of polarization of party competition.

- Estimates of ideological consistency of multiparty coalition presidential Cabinets.

- Influence of government's party composition on public expenditure.

- Comparative analysis of Latinobarometer-based results with analogous analyses using data from Eurobarometer, New Europe Barometer, Afrobarometer, and East Asia Barometer. 


\section{APPENDIX}

A few previous exercises can be contrasted with some of the results presented here. Given the differences in methods and scales in which they were developed, we will only compare political party's relative ordinal positions along the left-right dimension. First, the largest sample of party locations available, elaborated on the basis of expert judgments around 1993 by John Huber and Ronald Inglehart (1995) includes, out of 42 countries, four countries in Latin America. The parties shared in their and our analyses from Chile and Me xico coincide completely in their relative ordinal positions. Regarding Argentina, they locate UCR on the left to PJ, but our alternative positions can be explained by UCR's very recent moves, as discussed in the text. Regarding Brazil, we also register an exchange of relative positions between PSDB and PMDB, which may be attributed to the more recent experience of PSDB in government with morerightist-than-expected policies and management.

Second, an unpublished exercise, also based on expert judgments from 11 Latin American countries around 1994, was made available by Michael Coppedge (1997). His and our analysis share 38 parties, 5 of which are classified as 'other' or 'personalistic' by Coppedge. Almost all 33 remaining parties are located on coinciding relative positions on the left-right dimension in our analyses. The exceptions are three pairs of parties: PSDB and PMDB in Brazil, already mentioned in the above paragraph; as well as two pairs of center and right parties, PL and PC in Colombia, and PC and PN in Uruguay. In both the Colombian and the Uruguayan cases, the electoral systems enforced have induced high levels of party factionalisation. Coppedge also noted that "the Liberal party is the most difficult Colombian party to classify [due to] frequently diverging views of the experts", while, regarding Uruguay, he acknowledged that 
"the Colorados over the decades made a much more noticeable shift to the center" than registered in his classification.

Finally, a series of polls among party members were carried out in Latin American countries in 1996, 1998 and 199-2000 by Manuel Alcántara and Flavia Freidenberg (2001). We share 47 parties on whose relative positions on the left-right dimension there is extremely high coincidence. The only exceptions are two pairs already commented, PSDB and PMDB in Brazil and PC and PN in Uruguay, as well as UCS, which they locate on the left to MNR in Bolivia according to all but one of the six polls presented for this country. 


\section{NOTES}

1. Latinobarometer survey is carried out each year in 17 Latin American countries with representative samples of a population of 400 million inhabitants. In 10 countries the samples represent 100 percent of the population while in seven countries the data are from urban areas encompassing in average about two-thirds of total population. For surveys before 2002 we could use responses to only one of the questions since most party codes were mistaken, undecipherable or inexistent. Individual responses and row data were made available to us thanks to CIDE (Center for Research and Teaching in Economics), in Mexico City, as a member of the CLACSO network.

2. This is only slightly lower than analogous data previously published, for instance, for Western Europe: 83 percent for nine developed countries, in Inglehart and Klingemann (1987).

3. Interestingly, the early inclusion of latecomer Paraguay in the first survey, in 1995, shows a very low proportion of citizens able to place themselves on the left-right dimension, as low as 31 percent, while in the following democratizing years the proportion in the urban part of the country has increased up to 90 percent.

4. Estimates of proportions of people involved with non-ideological relations with parties may be underestimated for those countries in which Latinobarometer surveys are carried out only in urban areas, encompassing, in particular, only 60 percent of population in Brazil, 51 percent in Colombia, 49 percent in Venezuela and 30 percent in Paraguay. 
5. Available data for Western Europe and other developed countries are less polarized, a little more leftist and clearly less rightist; specifically, extreme country-averages were 4.6 and 6.2 in the nine West European countries surveyed by Inglehart and Klingemann (1987), and 4.7 and 6.3 in the twenty developed countries with data mostly from the World Values Survey compiled by Powell (2000, Table 7.1) 


\section{REFERENCES}

Manuel Alcántara Sáez, and Flavia Freidenberg (eds), Partidos políticos de América Latina,3 vol. (Salamanca 2001).

Charles D. Ameringer, Charles D. (ed), Political Parties of the Americas, 1980s to 1990s. (London 1992).

Ian Budge, 'Issues, Dimensions, and Agenda Change in Postwar Democracies: Long-term Trends in Party Election Programs and Newspaper Reports in Twenty-three Democracies', in William H. Riker (ed.) Agenda Formation (Ann Arbor, Michigan 1993), pp. 41-80.

Ian Budge and Hans Keman, Parties and Democracy: Coalition Formation and Government Functioning in Twenty States (Oxford 1990).

Ian Budge and Hans -Dieter Klingemann, 'Finally! Comparative Over-Time Mapping of Party Policy Movement', in Ian Budge, Hans-Dieter Klingemann, Andrea Volkens, Judith Bara, and Eric Tanenbaum, Mapping Policy Preferences. Estimates for Parties, Electors, and Governments 1945-1998 (Oxford 2001), pp. 19-50.

Ian Budge, Hans-Dieter Klingemann, Andrea Volkens, Judith Bara, and Eric Tanenbaum, Mapping Policy Preferences. Estimates for Parties, Electors, and Governments 19451998 (Oxford 2001).

Ian Budge, David Robertson and Derek J. Hearl (eds), Ideology, Strategy and Party Change: Spatial Analyses of Post-War Election Programmes in 19 Democracies (Cambridge 1987).

Francis G. Castles and Peter Mair, 'Left-Right Political Scales: Some 'Expert' Judgments', European Journal of Political Research, 12 (1984), pp. 73-88. 
Michael Coppedge, 'A Classification of Latin American Political Parties', University of Notre Dame: The Helen Kellogg Institute for International Studies, Working Paper \#244 (1997).

Anthony Downs, Anthony, An Economic Theory of Democracy (New York 1957).

John Huber and Ronald Inglehart, 'Expert Interpretations of Party Space and Party Locations in 42 Societies', Party Politics, 1, 1 (1995), pp. 73-111.

John Huber and G. Bingham Powell, Jr., 'Congruence between Citizens and Policymakers in Two Visions of Liberal democracy', World Politics, 46 (1994), pp. 291-326.

Ronald Inglehart and Hans D. Klingemann, 'Party Identification, Ideological Preference and the Left-Right Dimension among Western Mass Publics', in Ian Budge, David Robertson and Derek J. Hearl eds. Ideology, Strategy and Party Change: Spatial Analyses of Post-War Election Programmes in 19 Democracies (Cambridge 1987).

Jean A. Laponce, Left and Right: The Topography of Political Perceptions (Toronto 1981).

Michael Laver, Kenneth Benoit and John Garry, 'Extracting Policy Positions from Political Texts Using Words as Data', American Political Science Review, 97, 2 (2003), pp. 311-31.

Michael Laver and Ian Budge (eds), Party Policy and Government Coalitions (London 1992).

Michael Laver and W. Ben Hunt, Policy and Party Competition (London 1992).

Michael Laver and Norman Schofield, Multiparty Government. The Politics of Coalition in Europe (Oxford 1990).

Scott Mainwaring and Timothy R. Scully (eds), Building Democratic Institutions. Party Systems in Latin America (Stanford 1995).

G. Bingham Powell, Jr., Elections as Instruments of Democracy: Majoritarian and Proportional Visions (London 2000).

William H. Riker (ed), Agenda Formation (Ann Arbor 1993). 
David Robertson, A Theory of Party Competition (London 1976).

Giacomo Sani and Giovanni Sartori, 'Polarization, Fragmentation and Competition in Western Democracies', in Hans Daalder and Peter Mair (eds), Western European Party Systems (London 1983).

Donald P. Stokes, 'Spatial Models of Party Competition', American Political Science Review.57, 2 (1963), pp. 368-77. 
Table 1.

VOTERS ABLE TO PLACE THEMSELVES ON LEFT-RIGHT DIMENSION (in percentages)

\begin{tabular}{|c|c|c|c|c|c|c|c|c|}
\hline Country & Year: & 1995 & 1996 & 1997 & 1998 & 2000 & 2001 & 2002 \\
\hline Argentina & & 70 & 74 & 83 & 77 & 75 & 79 & 72 \\
\hline Bolivia & & --- & 81 & 81 & 70 & 73 & 68 & 80 \\
\hline Brazil & & 86 & 92 & 83 & 91 & 82 & 83 & 77 \\
\hline Chile & & 78 & 77 & 84 & 79 & 85 & 77 & 74 \\
\hline Colombia & & --- & 84 & 88 & 73 & 72 & 71 & 60 \\
\hline Costa Rica & & --- & 71 & 93 & 68 & 73 & 65 & 72 \\
\hline Ecuador & & --- & 80 & 88 & 84 & 76 & 75 & 60 \\
\hline El Salvador & & --- & 77 & 90 & 89 & 84 & 66 & 52 \\
\hline Guatemala & & --- & 58 & 91 & 78 & 84 & 63 & 54 \\
\hline Honduras & & --- & 74 & 92 & 68 & 83 & 84 & 75 \\
\hline Mexico & & 71 & 77 & 86 & 78 & 81 & 90 & 77 \\
\hline Nicaragua & & --- & 91 & 91 & 60 & 68 & 80 & 77 \\
\hline Panama & & --- & 96 & 83 & 83 & 88 & 83 & 72 \\
\hline Paraguay & & 31 & 65 & 74 & 76 & 93 & 85 & 90 \\
\hline Peru & & 78 & 85 & 78 & 85 & 85 & 77 & 71 \\
\hline Uruguay & & 87 & 97 & 91 & 91 & 95 & 94 & 91 \\
\hline Venezuela & & 66 & 78 & 83 & 86 & 79 & 90 & 78 \\
\hline Average & & 71 & 80 & 86 & 79 & 81 & 78 & 72 \\
\hline
\end{tabular}

Source: Latinobarometer, annual surveys 1995-2002. 
Table 2.

\section{TYPES OF VOTERS}

(in percentages)

\begin{tabular}{|c|c|c|c|c|c|c|}
\hline \multirow[b]{2}{*}{ Country } & \multirow[b]{2}{*}{ No.cases } & \multicolumn{3}{|c|}{ Able to Place on Left-Right } & \multicolumn{2}{|c|}{ Not Able to Place on Left-Righ } \\
\hline & & Total & Yes party & No party & Yes party & No party \\
\hline Argentina & 1200 & 72 & 15 & 57 & 4 & 24 \\
\hline Bolivia & 1242 & 80 & 48 & 32 & 3 & 17 \\
\hline Brazil & 1000 & 77 & 42 & 35 & 2 & 21 \\
\hline Chile & 1196 & 74 & 35 & 39 & 2 & 24 \\
\hline Colombia & 1200 & 60 & 34 & 26 & 11 & 29 \\
\hline Costa Rica & 1006 & 72 & 49 & 23 & 8 & 20 \\
\hline Ecuador & 1200 & 60 & 20 & 40 & 10 & 30 \\
\hline El Salvador & or 1014 & 52 & 19 & 33 & 10 & 38 \\
\hline Guatemala & 1000 & 54 & 12 & 42 & 8 & 38 \\
\hline Honduras & 1004 & 75 & 45 & 30 & 5 & 20 \\
\hline Mexico & 1210 & 77 & 47 & 30 & 5 & 18 \\
\hline Nicaragua & 1016 & 77 & 47 & 30 & 3 & 20 \\
\hline Panama & 1010 & 72 & 30 & 42 & 4 & 24 \\
\hline Paraguay & 600 & 90 & 42 & 48 & 1 & 9 \\
\hline Peru & 1224 & 71 & 27 & 44 & 4 & 25 \\
\hline Uruguay & 1200 & 91 & 59 & 32 & $<1$ & 8 \\
\hline Venezuela & 1200 & 78 & 41 & 37 & 2 & 20 \\
\hline Average & & 72 & 36 & 36 & 5 & 23 \\
\hline
\end{tabular}

Note: Voters are divided between those able and those not able to place themselves on the leftright dimension; within each group, a further division is made between those declaring a party preference ('Yes party') and those not declaring a party preference ('No party').

Source: Authors' own elaboration by crossing answers to several questions, as explained in the text, from Latinobarometer, 2002. 
Table 3.

VOTERS' SELF-PLACEMENT ON THE LEFT-RIGHT DIMENSION, 2002

\begin{tabular}{llllllllllllll} 
& Left & \multicolumn{1}{c}{ Percentage of Voters at Each Scale Point } & \multicolumn{3}{c}{ Right } \\
Country & 0 & 1 & 2 & 3 & 4 & 5 & 6 & 7 & 8 & 9 & 10 & Median & Mea \\
\hline Argentina & 5 & 2 & 5 & 7 & 7 & 41 & 7 & 6 & 7 & 3 & 10 & 5 & 5.3 \\
Bolivia & 9 & 5 & 4 & 7 & 5 & 35 & 8 & 6 & 8 & 2 & 11 & 5 & 5.1 \\
Brazil & 13 & 5 & 4 & 5 & 5 & 29 & 3 & 6 & 6 & 4 & 20 & 5 & 5.4 \\
Chile & 5 & 4 & 5 & 10 & 8 & 35 & 7 & 6 & 8 & 3 & 9 & 5 & 5.2 \\
Colombia & 2 & 4 & 2 & 3 & 2 & 26 & 6 & 5 & 8 & 8 & 34 & 7 & 7.0 \\
Costa Rica & 4 & 2 & 1 & 2 & 2 & 21 & 5 & 7 & 9 & 4 & 43 & 8 & 7.4 \\
Ecuador & 7 & 4 & 3 & 2 & 4 & 37 & 8 & 7 & 12 & 9 & 7 & 5 & 5.6 \\
El Salvador & 8 & 3 & 2 & 2 & 2 & 27 & 3 & 6 & 9 & 8 & 30 & 7 & 6.6 \\
Guatemala & 6 & 2 & 3 & 2 & 4 & 33 & 7 & 6 & 7 & 3 & 27 & 5 & 6.3 \\
Honduras & 10 & 2 & 1 & 1 & 1 & 17 & 2 & 1 & 2 & 2 & 61 & 10 & 7.6 \\
Mexico & 6 & 3 & 5 & 8 & 13 & 36 & 9 & 7 & 6 & 2 & 5 & 5 & 4.9 \\
Nicaragua & 11 & 3 & 4 & 3 & 5 & 19 & 5 & 5 & 8 & 4 & 33 & 6 & 6.3 \\
Panama & 7 & 5 & 5 & 6 & 10 & 28 & 11 & 9 & 5 & 3 & 11 & 5 & 5.2 \\
Paraguay & 7 & 1 & 3 & 5 & 4 & 40 & 6 & 6 & 9 & 5 & 14 & 5 & 5.7 \\
Peru & 5 & 4 & 4 & 7 & 6 & 39 & 7 & 5 & 9 & 5 & 9 & 5 & 5.4 \\
Uruguay & 5 & 4 & 6 & 11 & 11 & 25 & 7 & 8 & 11 & 5 & 7 & 5 & 5.2 \\
Venezuela & 12 & 4 & 3 & 3 & 4 & 22 & 4 & 5 & 7 & 3 & 33 & 6 & 6.2
\end{tabular}

Source: Authors' own elaboration with data from Latinobarometer, 2002. 
Table 4. LEFT-RIGHT LOCATION OF PARTY'S VOTERS

\begin{tabular}{llllll}
\hline ARGENTINA & & & & & \\
Parties: & IU & ARI-Frepaso & PJ & UCR & MEAN \\
Average position: & $\mathbf{2 . 2}$ & $\mathbf{4 . 6}$ & $\mathbf{6 . 1}$ & $\mathbf{6 . 3}$ & $\mathbf{5 . 3}$ \\
\hline No. of cases: & 41 & 32 & 93 & 17 & 181 \\
Standard deviation: & 1.9 & 2.1 & 2.5 & 2.5 & \\
Confidence interval: & $1.6-2.8$ & $3.8-5.3$ & $5.5-6.6$ & $5.1-7.5$ & \\
- & - & - & - & - & - \\
-
\end{tabular}

Parties:: IU: Izquierda Unida. ARI-Frepaso: Alianza Alternativa por una Re pública de IgualesFrente País Solidario. PJ: Partido Justicialista. UCR: Unión Cívica Radical.

\begin{tabular}{llllllll}
\hline BOLIVIA & & & & & & & \\
Parties:: & MAS & MIR & NFR & EJE & MNR & UCS & MEAN \\
Average position: & $\mathbf{2 . 7}$ & $\mathbf{4 . 3}$ & $\mathbf{5 . 1}$ & $\mathbf{5 . 3}$ & $\mathbf{5 . 8}$ & $\mathbf{6 . 1}$ & $\mathbf{5 . 1}$ \\
\hline No. of cases: & 37 & 113 & 216 & 71 & 113 & 67 & 595 \\
Standard deviation: & 2.9 & 2.5 & 2.7 & 2.9 & 3.0 & 3.2 & \\
Confidence interval: & $1.7-3.6$ & $3.8-4.7$ & $4.7-5.5$ & $4.6-6.0$ & $5.2-6.3$ & $5.3-6.8$ & \\
\hline
\end{tabular}

Parties:: MAS: Movimiento al Socialismo. MIR: Movimiento de la Izquierda Revolucionaria. NFR: Nueva Fuerza Republicana. EJE: Eje Pachakutic. MNR: Movimiento Nacionalista Revolucionario. UCS: Unidad Cívica Solidaridad.

\begin{tabular}{lllllll}
\hline BRAZIL & & & & & & \\
Parties: & PT & PSB & PMDB & PSDB & PFL & MEAN \\
Average position: & $\mathbf{3 . 7}$ & $\mathbf{5 . 5}$ & $\mathbf{6 . 8}$ & $\mathbf{7 . 2}$ & $\mathbf{7 . 2}$ & $\mathbf{5 . 3}$ \\
\hline No. of cases: & 256 & 18 & 73 & 56 & 40 & 424 \\
Standard de viation: & 3.1 & 3.4 & 3.2 & 2.5 & 3.1 & \\
Confidence interval: & 3.44 .1 & $3.9-7.0$ & $6.1-7.6$ & $6.5-7.8$ & $6.3-8.2$ & \\
-
\end{tabular}

Parties: PT: Partido dos Trabalhadores. PSB: Partido Socialista Brasileiro. PMDB: Partido do Movimiento Democrático Brasileiro. PSDB: Partido da Social Democracia Brasileira. PFL: Partido da Frente Liberal.

\begin{tabular}{llllllll}
\hline CHILE & & & & & & & \\
Parties: & PC & PS & PPD & PDC & RN & UDI & MEAN \\
Average position: & $\mathbf{2 . 2}$ & $\mathbf{3 . 1}$ & $\mathbf{3 . 7}$ & $\mathbf{5 . 0}$ & $\mathbf{6 . 3}$ & $\mathbf{7 . 7}$ & $\mathbf{5 . 1}$ \\
\hline No. of cases: & 20 & 83 & 74 & 106 & 41 & 114 & 421 \\
Standard deviation: & 2.4 & 1.8 & 1.6 & 2.1 & 2.7 & 1.9 \\
Confidence interval: & $1.1-3.3$ & $2.7-3.5$ & $3.3-4.0$ & $4.6-5.4$ & 5.47 .1 & $7.3-8.1$ & \\
\hline
\end{tabular}

Parties: PC: Partido Comunista. PS: Partido Socialista. PPD: Partido por la Democracia. PDC:

Partido Demócrata Cristiano. RN: Renovación Nacional. UDI: Unión Demócrata Independiente. 


\begin{tabular}{|c|c|c|c|c|}
\hline $\begin{array}{l}\text { Parties: } \\
\text { Average position: }\end{array}$ & $\begin{array}{l}\text { Independents } \\
6.1\end{array}$ & $\begin{array}{l}\text { Conservative } \\
6.7\end{array}$ & $\begin{array}{l}\text { Liberal } \\
7.6\end{array}$ & $\begin{array}{l}\text { MEAN } \\
7.0\end{array}$ \\
\hline No. of cases: & 145 & 55 & 366 & 406 \\
\hline Standard deviation: & 2.7 & 2.9 & 2.8 & \\
\hline Confidence interval: & $5.6-6.5$ & $5.9-7.5$ & 7.3-7.9 & \\
\hline
\end{tabular}

Parties:: Conservative: Partido Conservador. Liberal: Partido Liberal.

\begin{tabular}{llllll}
\hline COSTA RICA & & & & & \\
Parties: & PML & PAC & PLN & PUSC & MEAN \\
Average position: & $\mathbf{6 . 2}$ & $\mathbf{6 . 4}$ & $\mathbf{7 . 6}$ & $\mathbf{7 . 8}$ & $\mathbf{7 . 4}$ \\
\hline No. of cases: & 17 & 104 & 189 & 372 & 487 \\
Standard deviation: & 2.6 & 3.1 & 2.7 & 2.9 & \\
Confidence interval: & $4.9-7.4$ & $5.8-7.0$ & $7.2-8.0$ & $7.5-8.1$ & \\
\hline
\end{tabular}

Parties: PML: Partido Movimiento Libertario. PAC:.Partido Acción Ciudadana. PLN: Partido Liberación Nacional. PUSC: Partido Unidad Social Cristiana.

\begin{tabular}{llllllll}
\hline ECUADOR & & & & & & & \\
Parties: & PSP & ID & TSI & PRI & PSC & PRE & MEAN \\
Average position: & $\mathbf{3 . 0}$ & $\mathbf{3 . 6}$ & $\mathbf{5 . 7}$ & $\mathbf{6 . 1}$ & $\mathbf{6 . 6}$ & $\mathbf{6 . 7}$ & $\mathbf{5 . 6}$ \\
\hline No. of cases: & 15 & 40 & 27 & 63 & 101 & 25 & 239 \\
Standard deviation: & 2.7 & 3.1 & 1.7 & 2.3 & 2.1 & 2.8 & \\
Confidence interval: & $1.6-4.4$ & $2.6-4.6$ & $5.1-6.4$ & $5.5-6.7$ & $6.1-7.0$ & $5.6-7.8$ & \\
\hline
\end{tabular}

Parties: PSP: Partido Sociedad Patriótica 21 de enero. ID: Izquierda Democrática. TSI:

Transformación Social Independiente. PRI: Partido Renovador Independiente. PSC: Partido Social Cristiano. PRE: Partido Roldosista Ecuatoriano.

\begin{tabular}{llllll}
\hline EL SALVADOR & & & & & \\
Parties: & FMLN & PCN & PDC & ARENA & MEAN \\
Average position: & $\mathbf{2 . 8}$ & $\mathbf{6 . 2}$ & $\mathbf{7 . 2}$ & $\mathbf{8 . 3}$ & $\mathbf{6 . 6}$ \\
\hline No. of cases: & 83 & 13 & 14 & 138 & 195 \\
Standard deviation: & 2.7 & 3.6 & 2.2 & 2.5 & \\
Confidence interval: & $2.2-3.4$ & $4.2-8.2$ & $6.0-8.4$ & $7.8-8.7$ & \\
\hline
\end{tabular}

Parties: FMLN: Frente Farabundo Martí para la Liberación Nacional. PCN: Partido de

Conciliación Nacional. PDC: Partido Demócrata Cristiano. ARENA: Alianza Republicana Nacionalista.

\begin{tabular}{llll}
\hline GUATEMALA & & & MEAN \\
Parties: & PAN & FRG & $\mathbf{6 . 3}$ \\
Average position: & $\mathbf{6 . 3}$ & $\mathbf{6 . 8}$ & 120 \\
\hline No. of cases: & 92 & 28 & \\
Standard deviation: & 2.9 & 2.7 & \\
Confidence interval: & $5.7-6.9$ & $5.7-7.8$ &
\end{tabular}


Parties: PAN: Partido de Avanzada Nacional. FRG: Frente Republicano Guatemalteco.

\begin{tabular}{llll}
\hline HONDURAS & & & \\
Parties: & PL & PN & MEAN \\
Average position: & $\mathbf{8 . 1}$ & $\mathbf{8 . 2}$ & $\mathbf{8 . 2}$ \\
- No. of cases: & 223 & 312 & 448 \\
Standard deviation: & 3.2 & 3.2 & \\
Confidence interval: & $7.7-8.5$ & $7.8-8.6$ & \\
\hline
\end{tabular}

Parties: PL: Partido Liberal. PN: Partido Nacional.

\begin{tabular}{llllll}
\hline MEXICO & & & & & \\
Parties: & PRD & PRI & PAN & PVEM & MEAN \\
Average position: & $\mathbf{4 . 2}$ & $\mathbf{5 . 0}$ & $\mathbf{5 . 3}$ & $\mathbf{5 . 6}$ & $\mathbf{4 . 9}$ \\
\hline No. of cases: & 194 & 218 & 238 & 47 & 565 \\
Standard deviation: & 2.5 & 2.6 & 2.4 & 2.0 & \\
Confidence interval: & $3.9-4.6$ & $4.6-5.3$ & $5.0-5.6$ & $5.0-6.2$ & \\
\hline
\end{tabular}

Parties: PRD: Partido de la Revolución Democrática. PRI: Partido Revolucionario Institucional. PAN: Partido Acción Nacional. PVEM: Partido Verde Ecologista de México.

\begin{tabular}{lllll}
\hline NICARAGUA & & & & MEAN \\
Parties: & FSLN & PCN & PLC & $\mathbf{6 . 3}$ \\
Average position: & $\mathbf{4 . 8}$ & $\mathbf{6 . 0}$ & $\mathbf{7 . 5}$ & 477 \\
\hline No. of cases: & 183 & 19 & 351 & \\
Standard deviation: & 3.6 & 3.4 & 3.2 & \\
Confidence interval: & $4.2-5.3$ & $4.5-7.5$ & $7.1-7.8$ &
\end{tabular}

Parties: FSLN: Frente Sandinista de Liberación Nacional. PCN: Partido Conservador de Nicaragua. PLC: Partido Liberal Constitucionalista.

\begin{tabular}{lllllll}
\hline PANAMA & & & & & & \\
Parties: & CD & PRD & PDC & MOLIRENA & P.Arnulfista & MEAN \\
Average position: & $\mathbf{3 . 8}$ & $\mathbf{4 . 5}$ & $\mathbf{7 . 1}$ & $\mathbf{7 . 1}$ & $\mathbf{7 . 2}$ & $\mathbf{5 . 3}$ \\
\hline No. of cases: & 21 & 214 & 20 & 25 & 72 & 305 \\
Standard deviation: & 2.2 & 3.0 & 2.5 & 2.6 & 2.7 \\
Confidence interval: & $2.8-4.7$ & $4.1-5.0$ & $6.0-8.2$ & $6.1-8.2$ & $6.5-7.8$ &
\end{tabular}

Parties: CD: Cambio Democrático. PRD: Partido Revolucionario Democrático. PDC: Partido Demócrata Cristiano. MOLIRENA: Partido Movimiento Liberal Republicano Nacionalista. Partido Arnulfista.

\section{PARAGUAY}

Parties:

PLRA

ANR

Average position:

$5.4 \quad 6.4$

MEAN

6.1 
No. of cases:

Standard deviation:

Confidence interval:

$\begin{array}{ll}66 & 190 \\ 2.6 & 2.8 \\ 5.0-6.1 & 6.0-6.8\end{array}$

256

Parties: PLRA: Partido Liberal Radical Auténtico. ANR: Asociación Nacional Republicana.

\begin{tabular}{|c|c|c|c|c|c|c|}
\hline $\begin{array}{l}\text { PERU } \\
\text { Parties: } \\
\text { Average position: }\end{array}$ & $\begin{array}{l}\text { SP } \\
5.1\end{array}$ & $\begin{array}{l}\text { PAP } \\
5.3\end{array}$ & $\begin{array}{l}\text { UN } \\
5.4\end{array}$ & $\begin{array}{l}\text { PP } \\
5.8\end{array}$ & $\begin{array}{l}\text { AP } \\
6.4\end{array}$ & $\begin{array}{l}\text { MEAN } \\
5.4\end{array}$ \\
\hline No. & 11 & 193 & 72 & 83 & 12 & 329 \\
\hline Standard deviation: & 1.8 & 2.9 & 1.9 & 2.7 & 2.5 & \\
\hline Confidence interval: & $4.0-6.2$ & $4.9-5.8$ & $4.9-5.9$ & $5.2-6.4$ & $4.9-7.9$ & \\
\hline
\end{tabular}

Parties: SP: Somos Perú. PAP: Partido Aprista Peruano. UN: Unidad Nacional. PP: Perú Posible. AP: Acción Popular.

\begin{tabular}{lllll}
\hline URUGUAY & & & & PC \\
Parties: & EP/FA & PN & $\mathbf{7 . 6}$ & $\mathbf{5 . 1}$ \\
Average position: & $\mathbf{3 . 0}$ & $\mathbf{7 . 5}$ & 122 & 182 \\
\hdashline No. of cases: & 426 & 1.9 & 1.7 & 718 \\
Standard deviation: & 1.9 & $7.2-7.8$ & $7.4-7.9$ & \\
Confidence interval: & $2.8-3.2$ & &
\end{tabular}

Parties: EP/FA: Encuentro Progresista-Frente Amplio. PN: Partido Nacional. PC: Partido Colorado.

$\begin{array}{llllll}\text { VENEZUELA } & & & & & \\ \text { Parties: } & \text { MVR } & \text { PJ } & \text { AD } & \text { COPEI } & \text { MEAN } \\ \text { Average position: } & \mathbf{6 . 0} & \mathbf{6 . 3} & \mathbf{6 . 9} & \mathbf{8 . 6} & \mathbf{6 . 2} \\ -\mathrm{yo} \text { of cases: } & 360 & 98 & 74 & 15 & 543 \\ \text { Standard deviation: } & 3.8 & 3.1 & 3.4 & 2.8 & \\ \text { Confidence interval: } & 5.6-6.4 & 5.7-6.9 & 6.2-7.7 & 7.1-10.0 & \end{array}$

Parties: MVR: Movimiento V República. PJ: Primero Justicia. AD: Acción Democrática. COPEI: Partido Social Cristiano.

Note: For each party, the average position is the average self-placement of voters declaring their preference for the party. Total number of cases may be higher than the sum of party cases because the survey includes minor parties (with less than 10 cases each) that have not been considered in our analysis. Standard deviation $S=\left[\Sigma(\mathrm{M}-\mathrm{x})^{2} /(\mathrm{N}-1)\right]^{1 / 2}$, where $\mathrm{M}$ is the mean, $\mathrm{x}$ is the value of voter's self-placement, and $\mathrm{N}$ is the number of cases. Confidence interval $=\mathrm{x} \pm$ $2\left(\mathrm{~S} / \mathrm{N}^{1 / 2}\right)$, where $\mathrm{x}$ is the value of voter's self-placement, $\mathrm{S}$ is the standard deviation and $\mathrm{N}$ is the number of cases.

Source: Authors' own elaboration with data from Latinobarómetro 2002, as explained in the text. 
